\title{
Addressing Linguistic Diversity with Three Language Formula: A Case Study of Newa Schools in Newa Settlements
}

Toya Nath Bhattarai

\begin{abstract}
Nepal, as a multilingual nation, has constitutionally adopted mother tongue based multilingual education (MTB-MLE) policy in 1990. However, implementation of this policy into practice has been taking considerably a long time. This study, primarily focused on Newa Schools in Newa Settlement Campaign (NSNSC), looks into the efforts made by Nepalbhasa communities to implement the MTB-M LE policy by adopting a practical strategy of three language formula to facilitate students' learning through mother tongue, official language Nepali and international language English, thus, addressing the demands of socially and culturally diverse parents as well. This study has been carried out with ethnographic methods including participant observation, interviews, electronic recording, taking notes while recording and also using local language as suggested by Duranti (2000, pp.99-118). The data have shown that as a new experiment the three language formula has been a success story and a raiser of hope for future endeavors to implement MTB-MLE policy in the context of Nepal's linguistic diversity. What is still required is to chart a 'plan of action' supported by 'political will' of the government (central as well as local) and an active support of respective linguistic communities.
\end{abstract}

Keywords: linguistic diversity, code switching, medium of instruction, language policy, Nepalbhasa

\section{Introduction}

Nepal has been a country of linguistic diversity since antiquity or at least before its written history started but there are innumerable linguistic as well as ethnic communities in Nepal where the official language Nepali must be used more than their own mother tongue (Rai, 2005, p.531) in education and other day to day activities. Language coexistence, accommodation and mutual intelligibility are exemplary in Nepal. This illustrates Duranti's (2000) theory that code switching and the need to use two or three or four languages in various contexts become unavoidable in multilingual communities (p.18). Additionally, Nepal has to have English language at least to satisfy parents' desire to train their children with English from early grades and later to cope with international education, trade and other transactions. Thus, Nepal has to have at least three languages in schools and society i.e. home language (mother tongue), language of wider communication or official business/school education (Nepali) and, the language of international business (English). Likewise, when the recently designed federal set up of the government comes into full operation, the three language will be even more relevant and will probably have to be changed to even four language policy like in some cases of India (Abbi, 2015) which consists of mother tongues of respective speech communities, official language of provincial governments, lingua franca and the international language i.e. English.
For the time being, therefore, the three language formula has become the order of the day for the Nepalese linguistic communities and the multilingual schools. The schools of the Newa School Newa Settlement Campaign (hereinafter referred to as NSNSC), therefore, have already started three language formulas in their classrooms as well as in the extra-curricular activities.An attempt is made, in this article, to trace the genesis and development of trilingual approach adopted in the leading Nepalbhasha medium schools of the NSNSC in Kathmandu Valley.

\section{Theoretical Perspectives}

Duranti (2000) takes note of the concerns of linguistic anthropologists in linguistic diversity along with the fact that generative grammarians like Noam Chomsky and his students have developed a theory of Universal Grammar 'to hypothesize innate interpretive strategies that allow children to acquire any human language' across various speech communities as well as contexts (p.51) and adds that linguistic diversity is tied together with linguistic relativity, language contact and language mixing (p.83). This observation of a noted linguistic anthropologist entails that children can learn or at least understand the messages expressed in the languages of their school mates if appropriate learning environment is offered. He refers to 'code switching'- the practice of alternating between two or more languages in conversation or discourses- 
and indicates that it is a means to connect language and ethnicity in their daily affair. He says, "In bilingual communities where language switching is a daily affair, the choice of a particular language over another may index one's ethnicity or a particular political stance towards the relation between language and ethnicity" (p. 18).Taking clue from this hypothesis, as a matter of principle, in this research I intend to link my discussion on the trilingual medium approach to teaching adopted by the Nepalbhasa medium schools of Kathmandu as a strategic policy to address linguistically diversified composition of students' demography in the mother tongue based classrooms.

Nepal has been a country where a dominant language has to be learned at the cost of the mother tongues quiet for some time (Bandhu, 2007). Saying that this situation in any multilingual society including that of Nepal is harmful, Skutnab-Kangas (2007) puts the following arguments in support of multilingual education:

They (indigenous children) learn a dominant language at the cost of the mother tongue which is displaced, and later often replaced by the dominant language. Subtractive teaching subtracts from the child's linguistic repertoire, instead of adding to it. This dominant-language medium education prevents access to education, because of the linguistic, pedagogical and psychological barriers it creates... In this enforced language regime, the children undergoing subtractive education, or at least their children, are effectively transferred to the dominant group linguistically and culturally. This also contributes to the disappearance of the world's linguistic diversity, when a whole group changes language (p.1).

Can children learn multiple languages simultaneously? Lightbown and Spada (2003) the experts in the field of the process of language learning in bilingual contexts argue:

The evidences suggest that, when simultaneous bilinguals are in contact with both languages in a variety of settings, there is every reason to expect that they will progress in their developments of both languages at a rate and in a manner which are not different from those of monolingual children. Naturally, when children go on to have schooling in only one of those languages, there may be considerable differences in the amount of metalinguistic knowledge they develop and in the type and extent of the vocabulary they eventually acquire in the two languages. Nevertheless, there seems to be little support for the myth that learning more than one language in early childhood slows down the child's linguistic cognitive development (p.3).

Subhash (2013) in a study in Indian context describes the emergence and coverage of the three language formula in the following words:

The Three Language Formula (TLF) which emerged as a political consensus on languages in schooleducation was a strategy (not a policy) to accommodate at least three languages within the ten years ofschooling ... All India Council for Education recommended the adoption of theThree Language Formula in September 1956.

According to this formula, every child has to learn the following:

(i). The mother tongue or the regional language; (ii).

The official language of the union or the associate official language of the Union so long as it exists (official language of the union is Hindi and its associate official language is English); (i). Modern Indian language or a foreign language, not covered under (i) \& (ii) above and other than that used as the medium of instruction.

The study of Subhash ( 2013 ) in Indian linguistic diversity has found out that some states of India are implementing the three language formula while others are openly denying it. The effect of this debate has been that only Hindi and English languages are becoming widely spoken languages than others. Considering the linguistic diversity of India, three language policy was incorporated in the Indian National Education Policy 1986 pursuant to the recommendation of the National Commission on Education 1964-1966. Linguistic diversity plus 'less intense historical and cultural bias towards English' in India have paved the way for implementation of three language policyin India (Ammar et al., 2015, p. 117). The language situation of India and Nepal are similar particularly in respect of using mother tongues in education and federal administration. So Nepal's Language Commission of Nepal may learn from its counterpart in India.

\section{Policy Provisions}

The strong arguments in defense of MTB-MLE are accepted by policy makers in many parts of the world. Nepal also followed suit after the thirty year old 'one nation, one language' policy was dropped in favor of multilingual policy in 1990.The following justification given the constitution drafting committee as to why the mother tongue education provision was incorporated in the constitution is worth noting:

There are more than 40 languages (based on 1981 population census, now the number of languages has reached 123 according to 2011 census) and dialects which are spoken in Nepal. Out of them, many languages and dialects are gradually decreasing. Their scripts also are gradually coming to a stage of being endangered... The right to establish a school by any community for giving education to their children in their own mother tongue has been assured. This will have a positive influence of language on the children and will facilitate the learning process (Trans. Constitutional Suggestion Commission Document 'Explanatory Notes', 1990).

The drafters of 1990 constitution appear to have carefully thought about mother tongue education. However, they had not mentioned ways and means to implement it. Consequently, government schools were 
not keen on implementing this policy. Any effective innovation including the trilingual approach experimented by NSNSC, therefore, is considered a praiseworthy innovation against this background. The leaders of NSNSC have carried out this very important constitutional responsibility by devising or adapting this approach found useful at several places in the outside world. Based on these theoretical standpoints and the demands of the Nepalbhasa linguistic communities of the country, trilingual approach to teaching in the schools has been the practice since 1991. Jagat Sundar Bownekuthi, the first Nepalbhasha medium school, was established in Kathmandu as a first response to the Nepal's first ever constitutional provision on mother tongue education in 1990 that"Each community shall have the right to operate schools up to the primary level in its own mother tongue for imparting education to its own children" (The Constitution of the Kingdom of Nepal, 1990, Article 18, 2).

\section{NSNSC Initiative to Translate MTB-MLE Policy into Practice}

The NSNSC campaign effectively launched after the establishment of Modern Newa English School in 2004 is designed to address the language needs of Nepalbhasha students who come basically from Newa settlements with various linguistic and ethnic backgrounds to form multilingual classrooms. The coordinator of the NSNSC and concurrently the director of Modern Newa English School based in Durbar Square Kathmandu in a conversation with summed up his experience in these words:

The children of each speech community can benefit from other children in the trilingual approach. For instance, non-Newa students have been learning Nepalbhasa without any formal lessons and the Newa children have been getting opportunities to learn Nepali through conversation in formal and extracurricular activities with non-Newa children. This approach of the school has, thus, been benefitting all.I believe that languages are never against each other.

The student community in NSNSC schools consists of the children from, basically, two speech communities i.e. Nepabhasa and Nepali."They have to learn English as a third language right from the very beginning because the parents want their children to do so," adds Dipak. That is why every NSNSC school is dubbed as "Newa English school" to clearly indicate that the schools teaches not only through Nepalbhasha but also through Englishlanguage. Nepali language is mandatorily required according to government laws relating to medium of instruction. So the curricular as well as extracurricular activities for children are designed keeping in view the prevailing laws and the trilingual approach.

\section{Data Collection and Analysis}

The primary data for this were obtained during the piloting stage of my ethnographic case study of the leading Nepalbhasa medium schools-Jagat Sundar Bownekuthi and Modern Newa English School plus visits of other sample schools under the umbrella of NSNSC in the field. I later used ethnographic methods including participant observation, interviews, electronic recording, taking notes while recording and use of local language as suggested by Duranti (2000, pp 84-121).

Former Chancellor of Nepalbhasa Academy Satyamohan Joshi (2000) has this to say on three languages used in Nepalbhasa schools:

"एक, दुइ, तीन, चार, पांच, छ, सात, आठ, नौ, दश, जक धायेसयेके मते, अथेहे "One, Two, Three, Four, Five, Six, Seven, Eight, Nine, Ten, जक नं धायेसयेके मते, थस् गु मा भासं "छि, नसि, स्वं , पि, न्या, खु, न्हस, च्या, गुं, साँनं " धकास् नं धायेसये की"थ्व जुल मास्टर जगत सुन्दर मल्ल जु कनाथकुगु मूल मन्त्र १थ्व मूल मन्त्रया लिंधसाय जगत सुन्दर ब्वानेकुथिं किदं बुदिं न्यायेका च्वंगू जुल

The substance of this expression of Chancellor Joshi is: "Teach the number words, not in Nepali and/or in English only but teach them in Nepalbhasa words also. In other words, teach not only in Nepali or English but also in Nepalbhasa." This is the central idea of Master Jagat Sundar Malla (Joshi, 2000).

I had listened to nonagenarian Satya Mohan Joshi at Martin Chautari on 02 June, 2015 when he was discussing issues relating to Newars as indigenous people of Kathmandu Valley and the present status of Nepalbhasa. $\mathrm{He}$, among other things, opined that Nepal Bhasha is a mother language of us as Newars. Our children should be given early education in Nepalbhasa. He praised the efforts of NSNSC in this connection. In the same vein, he emphasized that there is an urgent need to compile a comprehensive tri-lingual dictionary with Nepalbhasa, Nepali and English entries together.

On March 11, 2017 Sunaguthi Newa English School in Lalitpur district celebrated parents' day. I too was invited as a guest of honor. Utilizing the opportunity, I recorded the speeches, students' songs and opinions of school managers. The activitiesof the programme were announced turn by turn in three languages namely Nepalbhasa, Nepali and English. A parent gave speech in Nepali while another spoke in Nepalbhasa. I spoke in Nepali and the chief guest Khyali Juju Madan Krishna Shrestha spoke in Nepalbhasa. Likewise the songs and dances besides national anthems were performed in both Nepali and Nepalbhasa. Children sang songs in English too. The program showed various activities of the students in three languages and to give the impression that MTB-MLE policy is implementable if the community of the school's catchment area supports it. I could understand it from the use of the languages according to the choice of the children. The fundamental thing was that there was language accommodation and language coexistence. There was a lot of language mixing and mutual intelligibility between two languages. The managers of the school told the audience that they are proud to be part of 
the NSNSC co-ordinated by Dipak Tuladhar.

On June 02, 2013 at Martin Chautari, I listened to Satya Mohan Joshi, the former chancellor of Nepalbhasha Academy and an authority on Nepalbhasa and Newa culture. He Praised the NSNSC saying that Newa Basti Newa School Campaign is a praiseworthy pioneer attempt to impart education in mother tongue. He recommended that teaching learning materials including a comprehensive tri-lingual dictionary of Nepalbhasha, Nepali and English should be prepared to promote mother tongues through education. I asked the nonagenarian expert of education and culture if he was aware of the contribution of Jagat Sundar Bownekuthi, a 27 years old Nepalbhasha medium school in using Nepalbahsa as medium of instruction. Joshi's answer was “Jagat Sundar Bownekuthi is a good step towards use of mother tongue in education. However it has been survive with the assistance of foreign donors. It has yet to be self-sustaining."

Luhbu Newa English School and Modern Newa English School run by Ganga Nemkul and Dipak Tuladhar have put posters with word meanings in three languages on the wall of their pre-primary classrooms and play grounds. I visited Luhbu Newa English School in April 2015 with Bishnu Chitrakar, a linguist and book writer specializing "in his native Nepalbhasa (Newar) language" and Devdas Manandhar, a language activist who has been working to promote Nepalbhasa as mother tongue. We were told that the school uses three languages in accordance with the policy of NSNSC. We observed some classes there to see how the students responded to the approach. The students were happy. I have taken photos and videos of the school activities. I have been visiting Modern Newa English School since 2012. It is a gateway to enter NSNSC because Dipak Tuladhar, the coordinator, has his office its premises. I have met several guardians and have participated in its major functions including graduation ceremonies. Dipak runs training sessions about teaching methods including use of three languages by demonstrating in classrooms and extracurricular activities.

On November 03, 2013 I travelled together with the mother tongue education campaigners led by Dipak Tuladhar, the Director of Modern Newa English School at Durbar Marg, Kathmandu being part of a car rally organized by the 'Newa Settlement, Newa School Campaign' and went through as many schools as possible out of the nearly 100 Nepalbhasa teaching schools of Kathmandu Valley from Tokha to Thencho where Nepalbhasa is either taughtas a subject or used as a medium of instruction. It started from the open theater in Tundikhel. By 8:30 in the morning, 20 plus cars packed with teachers and managers of the Nepalbhasa schools were ready to move. Dipak was instructing the drivers about how to go about it in a coordinated manner in the typically difficult roads of Kathmandu valley. He gave a brief interview to the Image Television. The rally went around stopping and having snacks at the receiving schools until 17:30 to close with a tea party at Mangal H.S. School Kirtipur. All settlements and schools there offered welcome and reception to the participants of the rally. All these schools told the visitors that they were dedicated to teaching/ teaching through Nepalbhasa, Nepali and English in the classes. In sum, all welcomed the NSNSC campaign enthusiastically.

In September 2017, I observed some classes in Jagat Sundar Bownekuthi. A note in Nepalbhasa describing that the three languages-Nepalbhasa, Nepali and English-are used in the school for instruction was hooked on the wall of a classroom. It reads as follows:

जिगु ब्वनेकुथीसजिगु ब्वनेकुथीया नां जगत सुन्दर ब्वनेकुथी खस् र थन नेपालभाषा ब्वंकी र नेपाली वअंग्रेजी भाय न ब्वंकीरथन कम्पुटर न स्यनी र बाँसुरी व मादल न स्यनीर कासा न म्हितकी रउकी जित जिगु ब्वनेकुथी तसक यस्र (My school: The name of my school is Jagat Sundar Bownekuthi. Nepalbhasa is taught and learnt here. Nepali and English is also taught and learnt here. Computer is also taught here. Playing flute and madal/drum are among other things that are taught here. Games are also played. Therefore, I like our school very much (My translation).

On 13 April, 2016, I had a conversation (an unstructured interview) with Ratna Devi Kasa, the 74 years old first former Principal of Jagat Sunder Bownekuthi. She mentioned, among other things, that they had to use the three languages in order to address the needs of the multiethnic composition of the classroom. She further added, they had to translate Nepali texts into Nepalbhasa as reading materials in the beginning and later, they resorted to photocopying as appropriate. They would interpret Nepali, social studies and mathematics texts in Nepalbhasa. Later, the Curriculum Development Center (CDC) produced some Nepalbhasa textbooks but they were in short supply. As a result, the school has to get several textbooks photocopied. Moreover, no curricula and textbooks for Nepalbhasa for grades 6,7 , and 8 have been produced by the CDC. That is, I and the NSNSC leaders believe, where the government needs to intervene in order to implement the constitutionally backed MTB-MLE policy.

Dipak Tuladhar in an interview on 06 August had told me that the children of non-Newar family start to speak Nepalbhasha within a short time they enter the Newa school. Likewise the Newa children learn Nepali through companionship with the Non-Newa school mates. Sunita Manandhar, the Principal of Jagat Sundar Bownekuthi, in a similar interview on 17 August 2018 told me: The students who come from non-Nepalbhasha speaking communities are given special attention for up to six months with a view to assist them as per their needs to be able to learn the lessons in Nepalbhasha medium with confidence. They have been performing well. I had a brief chat with Yashoda Pandey, girl student of Brahman origin by asking her why she took Nepalbhasha in her secondary education by joining Jagat Sundar Bownekuthi and if she had any difficulty in learning through Nepalbhasha. Her answer was that she liked Nepalbhasha as it was spoken in her neighborhood right from her childhood. She has been teaching Nepabhasa in Modern Newa English School for the last several years and has been employed there thanks to her knowledge of Nepalbhasha. It is probably against 
this background that the joint argument of Sharma and Phyak (2017) framed after studying MNES by way of case study that the use of Newari (sic) language in pedagogical practices, while giving equal importance to Nepali and English exemplifies flexibility in multilingual contexts.

\section{Working Policies of Government on Tri-Lingual Medium of Instruction}

The constitutions of 2007 and 2015 have retained with reforms the provisionsrelating to mother tongue education initiated by the 1990 constitution.Keeping this constitutional provision in view, the Three Year Interim Plan (2007-2010) of the government as prepared and published by the National Planning commission states: "Trilingual education policy shall be adopted besides imparting education to children through the medium of mother tongue." But it fails to explain how the three languages will be chosen. Nevertheless, it defines its working policy in this regard and says: "Community centered education policy shall be implemented with a view to promote access to education in mother tongues."..."In order to assure learning for children who speak local mother tongues, the school management committees may decide the medium language in consultation with local bodies." These policies have neither been implemented effectively nor withdrawn. Until withdrawn one must say the trilingual policy exists.

School Sector Reform Plan (2009-2015) had the plan to implement MTB-MLE in 7500 schools. It also mentioned that 'Based on linguistic survey including English language, opportunities for multilingual education will be expanded by appointing local language teachers and developing learning materials in local languages. Tenth Plan (2002-2007 has also mentioned policy for mother tongue education and has emphasized a special policy provision for promoting English in education:

In order to promote participation of various ethnic communities and linguistic groups in education, programs designed to give education in mother tongues shall be encouraged. By developing curriculum in such a way that education gives skills necessary for life, English shall be taught from grade I on the basis of capacity of schools (pp.456460).

Language policy in the new constitution, reiterating multilingualism as national language policy in general and federal arrangement for governance in particular, has called for several things including use of multiple languages in education, communication and official business. At least three languages will have to be used in provinces which are authorized to select its regional language spoken by majority of population as official language for province level official business. Besides, language will have to be learnt for inter-province communication and communication between provincial government and central government as well as for international communication. This is the situation whereby even four languages might be necessary for provinces. The new constitution states (Art., 7.2) as "In addition to the Nepali language, a province may, by provincial law, determine one or more than one national languages spoken by the majority of the population within the province as its official language(s)."

The constitution has given the responsibility to determine the criteria to be fulfilled for the recognition of the official language and make recommendations on languages to the Government of Nepal, (b) to make $r$ to language commission (Art., 287.6.a). The language commission has already been formed and has started to work.

\section{Challenges and Opportunities}

Koirala (2015), raises the following pertinent questions with regard to selection of language for education: How do you decide a language in a monolingual settlement? How about in the case of bilingual or multilingual class room? Or, like in politics, would you justify use of language spoken by majority population?Or would you apply distributive justice from the perspective of social justice ?Can the theory of language co-existence be applicable ? Can a strong language form the basis? Is it viable to make Nepali as a second language to teach those for whom it is a second language? Or is there any other way out? He prescribes that these decisions be made by local bodies.

Rai (2000) discusses the issue of how to select languages for using as media of instruction in a locality so that the "non-Nepali speakers of this country can enjoy the equal opportunity".He has dedicated three paragraphs to this issue and recommends a 'three-phase three group language plan' and makes a separate recommendation to save languages by introducing local languages as'regional official language' (p.537).

Regmi (2017) argues for provision of official language at local level instead of province level. It will open the door for many minority languages to be official language because the languages have direct bearing on the official businesses of local bodies. This argument goes in line with the constitution-based policy of empowering local bodies to make decisions about educational issues including selection of language of education. This, Regmi adds, will 'open door for many minority languages to be official language'.

Tuladhar (2007) said, Newa Basti Newa Schools [project campaign has been launched to establish Newa language based schools in Newa settlements. The project also helps to teach Nepal Bhasa as an optional subject in the existing schools wherever possible. Further, Tuladhar (2013), commenting on MLE in Nepal in the CERID conference 14th December, 2013 at Yalamaya Kendra also said, since languages are not against each other, they can co-exist and so can be taught together. Tuladhar himself runs a pre-primary school at Durbar Marga, Kathmandu. The school uses three languages, i. e. Nepalbhasa, Khas (Nepali), and English as media of instruction. According to Tuladhar, other schools under the umbrella of the Newa School in Newa Settlement Campaign (NSNSC) use Newa language as one of the teaching media besides Khas Nepali (sic) and English so that Non-Newar students also can 
easily adjust in the Newa schools. Newar and Non-Newar students are studying happily and Modern Newa English School (MNES) and Jagat Sunder (JSB).

Reporting the performance of MNES Matina, the Nepalbhasa magazine published by enthusiastic Newa intellectuals based in UK, comments:

Modern Newa English School (MNES) is a multilingual school where Nepalbhasa is used as a medium of teaching besides English and Khas (Nepali) Languages. As there are no language barriers at MNES, students are free to speak in their mother tongues. This makes them feel comfortable in the school as they are speaking the same language which they speak at home. This enables them to learn lessons in free and joyful atmosphere (Kansakar, 2009)

My field visit and discussion with head teachers and teachers of Kathmandu Valley based Nepal Bhasa medium schools (see Appendix I) reveals that they have been carefully using trilingual medium approach in their schools with a view to contribute to the Nepalbhasa communities' efforts to emancipate Nepalbhasa from hitherto prevailing monolingual policy. This campaign has raised awareness among Nepalbhasa speaking communities.

The introductory brochures of these schools and conversations with students, teachers and managers during my field visit there indicate that these and some more Nepalbhasa schools are technically affiliated to Modern Newa English School with its Director Dipak Tuladhar as their advisor for mother tongue education. They use the textbooks produced by experts of NSNSC for pre-primary level. They unanimously agree that this formula has been very successful in their teaching learning activities and attracting children from linguistically diverse communities. This strategy, if not a policy, contributes, according to them, to inclusion in education by minimizing linguistic barriers and facilitating access and quality in education.

\section{Some Debates on the Trilingual Formula}

Eminent linguist, Seel, Yadava, and Kadel, (2015), argued for trilingual policy for Nepal and recommended in principle the trilingual approach (mother tongueplus Nepali plus English) to help every individual child learn 2-3 languages through MTB-MLE. Two leading teachers of English education at TU Education faculty namely Vishnu Singh Rai and Prem Phyak questioned the recommendation from the floor basically on the ground that it goes against the spirit of promoting multilingual education by limiting the pedagogy in three languages only.

In a search for opinions about the three language approach I had posted a question through my facebook wall on June 27, 2015 asking the public if this policy can be useful in Nepal. I had received three interesting and pertinent responses. My research question was: Can somebody please comment on the following statement of Clynein the light of its relevance in our context?

Response 1. Prem Phyak: "Trilingualism again creates very fixed boundaries among languages. It depends upon whether the approach is monoglossic or heteroglossic. Trilingual policy in India has not helped many tribal children to access basic education. It's all about hierarchization of languages. If we want to promote "true" and "egalitarian" multilingualism who(sic) think about multilingual practices as boundary-crossing thing." Response 2: Dipak Tuladhar नेपालको सन्दर्भमा कार्यालयमा २ भाषा (नेपाली र स्थानिय मौलिक मातृभाषा) स्कूलमा ३ भाषा (नेपाली, अंग्रेजी र स्थानिय मौलिक मातृभाषा) नीति अपनाउनु पर्छ। चौठौ भाषाको रूपमा कसैले हिन्दी, चाइनिज, कोरियन आदि पढाउन चाहे त्यो, त्यस स्कलको आन्तिरक कुरो हो, तर ३ वटा भाषालाई भने अनिवार्य गर्नु पई, यो कुरा सरल र सम्भव पनि छ । [In the context of Nepal, two languages (Nepali and one local language or original mother tongue) should be used in government offices and use of three languages (Nepali, English and local original mother tongue) should be the policy in schools. If any school wants to teach Hindi, Chinese, Korean and the like in their internal matter but in any case three languages should be made compulsory. This is an easy and possible thing to do]. Dipak Tuladhar here is no other than the coordinator of NSNSC and Director of MNES.

Response 3: Netra Tumbahangphe (त्रिभाषीय व्यवस्था म समर्थन गई । [I endorse trilingual arrangement, June 28, 2015 at 3:41am].

Netra Tumahangphe is an intellectual whose mother tongue is Limbu and works as a freelance researcher being focused on advocating emancipation of ethnicities from discrimination of any form including that based on the ground of language.

Last but not the least, I have given the quote from Som Bahadur Dhimal a veteran mother tongue education activist and rewarded columnist of Gorkhapatra's mother tongue page who has in sum has said about the overall performance of MNES, the pioneer of three language formulas in Nepal that it is imitable by all mother tongue speakers .

\section{Conclusions}

Drawing on the above theories, expert opinions and quotations, review of repeatedly issued policy pronouncements and, more importantly my electronic records, research notes in respect of the pedagogic handson experiences of practitioners involved in NSNSC, I have made the following conclusions regarding application of three language formula in schools that have MTB-MLE in their agenda.

a. Linguistic diversity is a salient feature of Nepalese society and Nepal's government and people have been searching for strategy/strategies to address it particularly in education and public administration.The managerial and pedagogic experiences of Nepalbhasa schools of Kathmandu valley summed up while implementing three language approach have been found practicable and so 
praiseworthy. They have been found as raisers of hope.

b. Two leading community funded schools of Kathmandu namely Jagat Sundar Bownekuthi and Modern Newa English School have been using mother tongue as medium of instruction since their inception in addition to Nepali and English on practical ground i.e. Nepal Bhasha is the mother tongue, Nepali is the official and school language and English is the language of higher education and of international business. The stakeholders and promoters of the NSNSC believe that languages can co-exist provided no political prejudice exists in managing them. They are rewarded by various institutions in recognition of their outstanding performances in terms of student achievements.

c. Debates about how to implement the MTB-MLE have been going on both in the public and private sector. The experience of NSNSC particularly in respect of trilingual approach is worth imitating in terms of risk and benefits if looked at from the perspective of medium of instruction and from the perspective of using mother tongue in public management in the long run because if languages are promoted through education the new generation will use it to pave way for language survival. The three decade long experience of NSNSC can be worth imitating for other mother tongues too.

d. The leading schools of NSNSC and their managers have been struggling to make MTB-MLE a success story in the linguistic communities by means of trilingual approach to primary level teaching and transition to upper levels i.e. secondary and tertiary levels.

e. The achievements of Jagat Sundar Bownekuthi and the NSNSC, I believe, are good examples of the successful application of the three language formula as a strategy to address linguistic diversity both in the society and in the class room if looked at from the perspectives of the social and cultural diversity in Nepalese linguistic communities (Bhattarai, 2015). The argument as to whether trilingual approach can limit multilingual approach may be one of the good issues for further research in future. At this stage, however, both the government of Nepal and the NSNSC as an initiative to raise awareness among the community supported Nepalbhasha schools have found the three language approach as the most viable strategy to move ahead to address linguistic diversity in the contemporary societal context.

\section{References}

Abbi, A. (2015). Human cognitive abilities and safeguarding linguistic diversity.Keynote Speech delivered at the Annual Conference of the Linguistic Society of Nepal November 26, 2015.

Ammar, A., Naveen, A. L. I., Fawad, A., \& Qasim, K. (2015). Language policy and medium of instruction issue in Pakistan. Acta Linguistica Asiatica, 5(1), 111124.

Bandhu, C. (2007). Language competition: English at the cost of what? Sanskrit at the cost of what ? Paper presented at Nepal Multilingual Education Symposium
October 1-3, 2007, Lalitpur, Nepal.

Bhattarai, T. (2015). Trilingual approach in Newa schools of Kathmandu Valley (un published paper). A power points presentation in the 36th Annual Conference of the Linguistic Society of Nepal (LSN), November 2628, 2015 in Kathmandu.

Duranti, A. (2000). Linguistic anthropology. Cambridge: Cambridge University Press.

Joshi, S. (2000). Bintuna-Dechha (Message of Good wishes). In Jagat Sundar Bownekuthiya Jhidan Bundin Lasatay Lumanti Pau (10th Birthday Anniversary of Jagat Sundar Bownekuthi Commemorative Issue. Kathmandu: Jagat Sundar Bownekuthi.

HMG Ministry of Law and Justice. (1990). The constitution of the kingdom of Nepal 1990. Kathmandu: Author.

Kansakar, T. (2009). Newar/ Nepalbhasa and linguistic survey of Nepal. Matina, 3(2).

Koirala, V. (2015).Sanghiyatale Khojeko Sthaniya Shikasha (Local education required by federalism). Shikshakhabar, 1.

Lightbown, P., \& Spada, N. (2003). How languages are learned. Oxford: Oxford University Press.

National Planning commission. (2002). Tenth plan (20022007). Kathmandu: Author.

National Planning commission. (2007). Three year interim plan (2007-2010). Kathmandu: Author.

Rai, V. (2005). Endangered languages, moribund languages, and killer languages. Contemporary Issues in Nepalese Linguistics, Silver Jubilee Issue. Kathmandu: Linguistic Society of Nepal.

Regmi, B. (2017). Issues on the policy of official language(s) in Nepal (Unpublished paper). A paper presented at the annual conference of the Linguistic Society of Nepal, November 25-27, Kathmandu.

Seel , A., Yadava, Y., \& Kadel, S. (2015). Medium of instruction and language of education: Ways forward for education policy planning and practice in Nepal. Kathmandu: Author.

Sharma, B. and Phyak. P. (2017). Neoliberalism, linguistic commodification, and ethnolinguistic identity in multilingual Nepal. Language in Society 46, 231-256.

Skutnabb- Kangas, T. (2007). Indigenous children's education and indigenous languages expert paper written for the United Nations permanent forum on indigenous issues. Presented on September 26, 2007 in TU Central Department of Linguistics, Kathmandu.

Subhash. (2013) Three language education formula in multilingual India: Problems and prospects. International Journal of Educational Research, 1(4), 327-247.

The Constitutional Suggestion Commission. (1990). Explanatory notes of the constitution of the kingdom of Nepal1990. Kathmandu: Author

Tuladhar, D. (2007). Newa schools in Newa settlements project. Quarterly Magazine Matina, 2(1).

Bhattarai, Toya Nath did his M. Ed. from Tribhuvan University in 1987 and studied Public Policy Analysis under Hubert Humphrey Fellowship at The American 
University in Washington D. C. He worked for the Government of Nepal for thirty three years as a policy analyst and has presented papers based on policy research in various national and international conferences. He has been working for a $\mathrm{PhD}$ on MLE policy for Nepal's linguistic minorities with focus on Nepal Bhasa schools. Professionally, at the present time, he is Principal of Jirikhimti Multiple Education Campus of Tribhuvan University, Nepal.

Email: btoyanath@yahoo.com 